\title{
Power Engineering of Brake System of a Heavy Duty Agricultural Motor Vehicle
}

\author{
Melinda Menyhártné Baracskai \\ Faculty of Engineering Sciences, Department of Mechatronics and Machine Designes, HUNGARY-9026 Györ, Egyetem tér 1.
}

\section{BIOGRAPHICAL NOTES}

Melinda Menyhártné Baracskai, She is a graduate of Faculty of Traffic Engineering, Széchenyi István University (SZE) of Hungary of Győr. Currently works as an Assistant Lecturer of Thermofluid Team of Department of Mechatronics and Machine Designes within a Széchenyi István University. The research is concentrated on the thermal problems of the brake system of an agricultural motor vehicle. Investigation cover : when the brake is operating in a thermally safe way under various conditions of cooling down, optimization of wheel body, research of friction and oil testing.

\section{KEY WORDS}

Agricultural motor vehicle, disc brake, brake oil, brake application, temperature, heat removal.

\section{ABSTRACT}

Thermal problems of brake system of a heavy duty engine are analyzed in the article. The agricultural motor vehicle is able to travel at $40 \mathrm{kph}$ speed and its weight is 30000 $\mathrm{kg}$. Owing to friction of brake discs, significant amount of heat is released when brake of this vehicle of large weight is applied. For the brake to operate in a reliable way, it is essential to prevent overheating.

Design of brake system is described in the article. Description of experiments conducted for inspecting heating and evaluation of results are also included in it. After that, the heat released during brake application is determined. It is also discussed when the brake is operating in a thermally safe way under various conditions of cooling down. The article shows at which temperature damage of cooling oil occurs. This essay means further development of the results described in work [11]. The analysis constitutes part of the project aiming at optimization of wheel body.

\section{Thermal description of process of braking}

During the operating time of the motor vehicle, the brake system can be in two different modes: open or closed.

If the vehicle performs translational motion and no brake application occurs, then the brake device itself is in open condition.

At the time of brake application, the hydraulic system presses the rotating discs and the oil removes from between the discs. Efficient flow of oil is facilitated by that the brake discs are equipped with fluted friction pad. When the discs are closed, friction 
occurs; as a result, the vehicle's kinetic energy is transformed into friction work while heat is produced.

When brake application is finished, discs open again, so the brake oil flows between the brake discs again. Oil is heated there and lashes against the housing under the effect of the centrifugal force produced by the rotational motion. The oil transfers one part of the produced heat amount to the environment. The heat amount remaining in the system is removed from the system by means of a water-cooled heat exchanger. Oil is conveyed to the oil cooler connected to the inspected unit by means of a pump ensuring 16 litre/min volume flow rate.

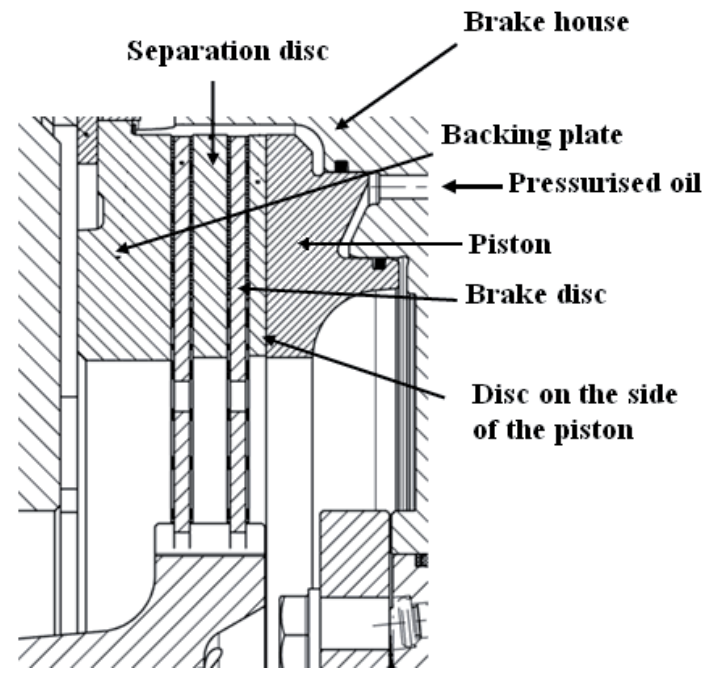

Fig. 1: Main elements of the brake device found in the wheel body.

\section{Measurement, measuring results}

The measurement was performed by means of wheel brake structure and brake efficiency testing instrument of Greening type. With proper loading, comparative wear measurement and brake efficiency test can also be made with it. The instrument can be applied for slow-down or permanent speed drive.

Data recording was done by means of Hottinger Spider Mobil 16-channel data recorder.

An assembly of half of a bridge body closed with a clamping disc and a wheel body supported in bearings on it is mounted on the instrument as a test unit. The half of bridge body closed with a clamping disc can be found in the stator of the equipment.
Because of the limited inertia of the equipment, the rotating flywheel is not connected directly to the wheel body, but to the properly designed sun wheel. The flywheel imitates the inertia of the vehicle.

In order to achieve realistic results, it is necessary to create and use the outside cooling effect of wind. It is provided by the air flow produced by a ventilator through a pipe system of $0,4 \times 0,6 \mathrm{~m}$ section.

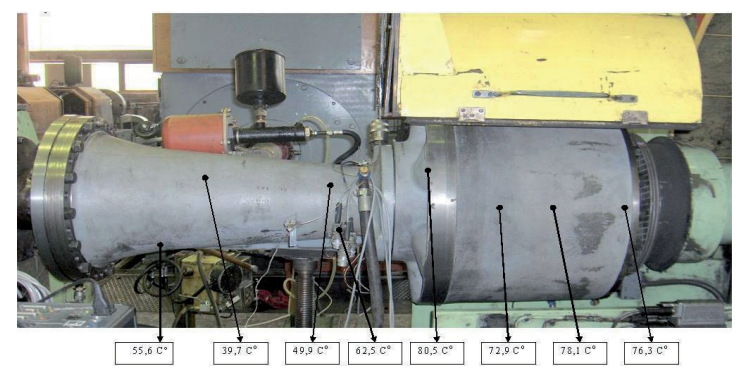

Fig. 2: Temperature values measured on the bridge body.

The temperature measurement on the separating disc was done as follows:

The separating disc is $12 \mathrm{~mm}$ wide. The thermometer is placed in the centre of the separating disc in a hole of $3 \mathrm{~mm}$ diameter and $50 \mathrm{~mm}$ depth.

\section{Temperature form of the disc brake}

When the heat produced during brake application is transmitted by heat convection, density of heat flux can be generated as follows [1]:

$\dot{q}=\frac{\lambda}{\delta}\left(t_{1}-t_{2}\right)\left(W / m^{2}\right)$

$R_{\text {ell }}=\frac{\delta}{\lambda}$

Where: $\dot{q}$ - Density of heat flux $\left(\mathrm{W} / \mathrm{m}^{2}\right), \lambda$ - Coefficient of thermal conduction $(\mathrm{W} / \mathrm{mK}), \delta-$ Wall thickness ( $m), \mathrm{t}_{1} ; \mathrm{t}_{2}$ - Temperature values of the elements participating in heat conduction (K), Rell Resultant resistance $\left(\mathrm{m}^{2} \mathrm{~K} / \mathrm{W}\right)$

$$
\begin{aligned}
& \lambda s z=50 \cdot \frac{W}{m K} \\
& \lambda a=43 \cdot \frac{W}{m K} \\
& \lambda s=0,3 \cdot \frac{W}{m K}
\end{aligned}
$$


Where: $\lambda$ sz - Coefficient of thermal conduction of grey cast-iron, $\lambda \mathrm{a}$ - Coefficient of thermal conduction of steel, $\lambda \mathrm{s}$ - Coefficient of thermal conduction of the friction layer

Resultant resistance can be generated as sum of partial resistances:

$R_{\text {ell }}=R_{\text {elvt }}+R_{1 s r}+R_{f t}+R_{2 s r}+R_{t t}$

$R_{\text {ell }}=7,5427 \mathrm{~m}^{2} \mathrm{~K} / \mathrm{W}$

Transposing the equation and from the measurement knowing the temperature of the separating disc telvt $=298^{\circ} \mathrm{C}$, we can get amount of density of heat flux:

$\dot{q}=28902,227 \approx 29 \cdot 10^{3} \frac{\mathrm{W}}{\mathrm{m}^{2}}$

Then we can determine temperature of each wall step by step:

$$
\begin{aligned}
& t_{\text {elvt-s}}=t_{\text {elvt }}-\dot{q} \cdot R_{e l v t}=294,521^{\circ} \mathrm{C} \\
& t_{s-f t}=t_{e l v t-s}-\dot{q} \cdot R_{s}=197,854^{\circ} \mathrm{C} \\
& t_{f t-s}=t_{s-f t}-\dot{q} \cdot R_{f t}=194,483^{\circ} \mathrm{C} \\
& t_{s-t t b}=t_{s-d o t}=t_{f t-s}-\dot{q} \cdot R_{s}=97,817^{\circ} \mathrm{C} \\
& t_{t t k}=t_{s-t t b}-\dot{q} \cdot R_{t t}=79,262 \approx 80^{\circ} \mathrm{C} \\
& t_{d o t-d}=t_{s-d o t}-\dot{q} \cdot R_{d o t}=94,338^{\circ} \mathrm{C} \\
& Q=\dot{q} \cdot A \cdot \tau=5254,8 J
\end{aligned}
$$

\section{Where:}

Rell - resultant resistance $\left(\mathrm{m}^{2} \mathrm{~K} / \mathrm{W}\right), R_{\text {dot }}$ - resistance of the disc on the piston side $\left(\mathrm{m}^{2} \mathrm{~K} / \mathrm{W}\right), R_{l s r}$ - resistance of friction pad 1 ( $\left.\mathrm{m}^{2} \mathrm{~K} / \mathrm{W}\right), R_{f t}$ - resistance of the brake disc $\left(\mathrm{m}^{2} \mathrm{~K} / \mathrm{W}\right), R_{2 s r}$ - resistance of friction pad 2 ( $\left.\mathrm{m}^{2} \mathrm{~K} / \mathrm{W}\right), R_{t t}$ - resistance of the supporting disc $\left(m^{2} K / W\right)$, Relvt - resistance of the separating disc $\left(m^{2} \mathrm{~K} / \mathrm{W}\right)$, telvt - temperature of the separating $\operatorname{disc}\left({ }^{\circ} \mathrm{C}\right), t_{\text {elvt }-s}$ - temperature of the contact surface of the separating disc and the friction pad $\left({ }^{\circ} \mathrm{C}\right), t_{s-f t}$ - temperature of the contact surface between the friction pad contacting the separating disc and the brake disc $\left({ }^{\circ} \mathrm{C}\right), t_{f t-s}$ - temperature produced between the brake disc and the friction pad contacting the supporting $\operatorname{disc}\left({ }^{\circ} \mathrm{C}\right), t_{s-t t b}$ - temperature of the contact surface between the friction pad and the supporting $\operatorname{disc}\left({ }^{\circ} \mathrm{C}\right), t_{t k}$ - temperature of the outside surface of the supporting disc $\left({ }^{\circ} \mathrm{C}\right), t_{s-}$ dot - temperature of the contact surface between the friction pad and the piston side disc $\left({ }^{\circ} \mathrm{C}\right), t_{\text {dot }}-$ $d$ - temperature of contact surface between the piston side disc and the piston $\left({ }^{\circ} \mathrm{C}\right), Q$ - Amount of heat flow through the wall $(J), \tau-$ Time (sec.), $A$ - Surface $\left(\mathrm{m}^{2}\right)$.

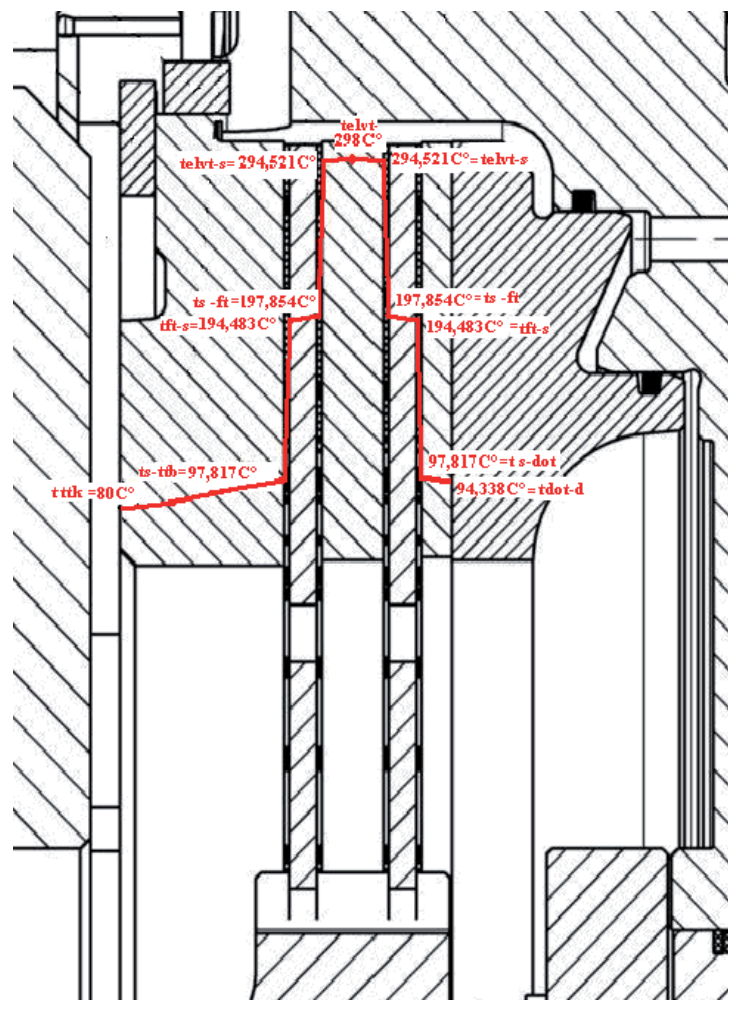

Fig. 3: Temperature distributiony.

\section{Determination of amount of heat released dur- ing brake application}

Using the energy equation of the process of braking:

$Q_{\text {braking }}=\frac{1}{2} \cdot I \cdot \omega^{2}+m \cdot \frac{v^{2}}{2}(J)$

$\omega=\frac{2 \cdot \pi \cdot n}{60}$

Where: $I$ - Moment of inertia of the total rotating mass participating in the process of braking (598.4 $\left.\mathrm{kg}^{2} \mathrm{~m}\right), \omega$ - Rotational speed (55.07 rad/sec), $m$ - Vehicle mass $(30000 \mathrm{~kg}), \nu$ - Rate of travel of vehicle (40 kph), $n$ - Revolution number of sun wheel (525.9 rev/min).

Supposing that power efficiency of sun-andplanet gear is $97 \%$, the amount of heat released 
during one brake application is Q1 braking = $2682.63 \mathrm{MJ}$

The amount of heat calculated with the energy equation, which is the sum of the rotational and translational motion, is the same as the heat amount removed from the system after braking. The heat released at the time of braking is removed by means of air and oil cooling as mentioned above.

Prior to this article, a study was published by the author (Thermodynamical examination of the oily disc brake of an agricultural motor vehicle, Periodica Politechnica, Transportation Engineering, Budapest. Just being published) in which values of coefficient of heat transfer necessary for the determination of heat removal are calculated for the air outside the brake drum $\left(20^{\circ} \mathrm{C}\right)$ and the internal coefficient of heat transfer of the wheel body is also calculated by means of criterion equations.

The external coefficient of heat transfer can be given as follows by the number Nu from Article [6]:

$\alpha_{1}=\frac{N u \cdot \lambda}{d}$

Where: $d$ - Diameter of wheel body $(0.62 \mathrm{~m}), v$ - Kinematic viscosity for ambient temperature of $20 \mathrm{C}^{\circ}$ $\left(15.7 \cdot 10^{-6} \mathrm{~m}^{2} / \mathrm{sec}\right), \lambda$ - Coefficient of heat conduction $(0.025 \mathrm{~W} / \mathrm{mK})$.

The value of Reynolds number is 438343.949 .
$N u=c \cdot \operatorname{Re}^{n}$

Values of $\mathrm{c}$ and $\mathrm{n}$ constants can be determined from Table 16 [4]: $\mathrm{n}$ - In case of flow becoming eddy, the tangent of angle of obliquity of curve.

It can be seen in the diagram showing the relation between numbers $\mathrm{Re}$ and $\mathrm{Nu}$ [4] that the function is linear therefore we can give the Nu number belonging to the wheel body of $0.62 \mathrm{~m}$ diameter.

Substituting then extrapolating, we get value of Nu number:

$N u_{62}=952,416$

Value of coefficient of heat transfer $\alpha_{62}$ is:

$\alpha_{62}=38,40 \frac{\mathrm{J}}{\mathrm{m}^{2} s K}$

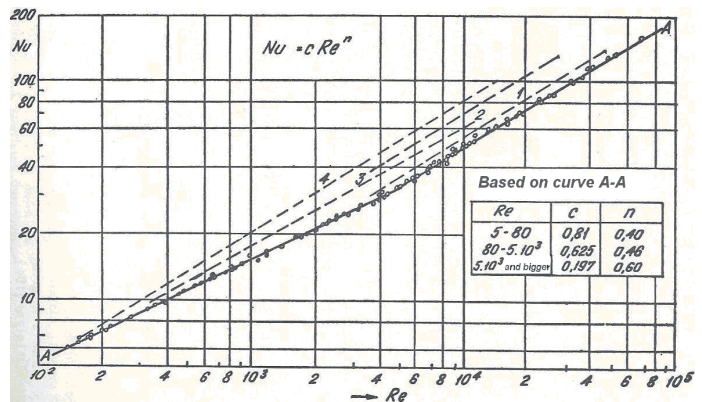

Fig. 4: Heat transfer of cylinder in case of perpendicular air flow [4].

Table 1: Thermodynamic characteristics.

\begin{tabular}{|l|l|l|l|l|l|}
\hline $\begin{array}{l}\text { Rate of travel } \\
\mathbf{( k p h )}\end{array}$ & $\begin{array}{l}\text { Heat-transfer } \\
\text { coefficient 1 } \\
\left(\mathbf{J} / \mathbf{m}^{2} \mathbf{s K}\right)\end{array}$ & $\begin{array}{l}\text { Heat amount 1 } \\
\text { removed by air } \\
\text { cooling } \mathbf{( J )}\end{array}$ & $\begin{array}{l}\text { Heat-transfer } \\
\text { coefficient 2 } \\
\mathbf{( J / m 2 s K )}\end{array}$ & $\begin{array}{l}\text { Heat amount 2 } \\
\text { removed by air } \\
\text { cooling (J) }\end{array}$ & $\begin{array}{l}\text { Total heat amount } \\
\text { removed by air } \\
\text { cooling (J) }\end{array}$ \\
\hline 10 & 9,60 & 203,04 & 8,0 & 197,13 & 400,17 \\
\hline 20 & 19,02 & 401,98 & 16,02 & 394,32 & 796,31 \\
\hline 30 & 28,83 & 609,27 & 24,03 & 591,52 & 1200,79 \\
\hline 40 & 43,83 & 926,26 & 38,40 & 945,1 & 1871,36 \\
\hline
\end{tabular}

Heat-transfer coefficient 1 means the heat transfer coefficient for the flat plate of wheel body, while heat-transfer coefficient 2 for the cylindrical surface of wheel body. Similarly, heat amount 1 removed by air cooling means the heat removed through the flat plate of the brake drum, while heat amount 2 through the cylindrical shell of the brake drum. Note that the brake drum is limited with two flat plates, so amount of heat removed through these surfaces will be double of this value.

Under normal operating circumstances, heat is

removed by air cooling and oil cooling

The study determines the greatest number of brake applications possible in one hour under various circumstances.

In each case, the vehicle is slowed down from the rate of travel with a very short emergency braking in 2 seconds till full stop. Rate of travel of vehicle will be 10, 20, 30, $40 \mathrm{kph}$ in the following.

The following cases are examined in the article:

- It determines how many is the greatest number of brake applications permitted when air cooling 
and oil cooling are operating simultaneously.

- It analyses the critical event when the oil cooler does not operate, and heat removal is done only by air cooling.

- After that it shows how the change of wall temperature of wheel body influences number of brake applications.

\section{Demonstration of results \\ Determination of possible number of brake applications in case of only air cooling:}

When stopping full from rate of travel of $40 \mathrm{kph}$, heat of 2682963.67 will be produced during one brake application.

By means of air cooling, total amount of Qair cooling $=1871.36 \mathrm{~J}$ can be removed.

The oil cooler can remove heat of $\dot{Q}_{0}=7396,73$ $W$. If the air cooling is operating alone, we can remove heat amount produced of $2694758.4 \mathrm{~J}$ in 24 minutes. Well, it can be seen from this that emergency braking is possible only 2 times in one hour in case of air cooling. Therefore, necessity of oil cooling is confirmed.

If in addition to the air cooling oil cooling is also operating as we can expect it, then the brake can be applied 12 times for 2 seconds in one hour.

In the following, under various conditions we will examine tendency of number of brake applications done safely from the viewpoint of failure of equipment.

Let us change the speed of the vehicle. It will be $10 \mathrm{kph}$ in the first case, after that $20 \mathrm{kph}, 30 \mathrm{kph}$ and then $40 \mathrm{kph}$. Examine how much time will be necessary for removing the heat produced in case of $55^{\circ} \mathrm{C}$ wheel body wall temperature if air cooling is applied alone.

When applying the brake, we will apply it until the vehicle fully stops. Therefore the number of permitted brake applications is relatively low. In reality, we will not apply the brake till full stop, so number of brake applications may be higher in actual events. If in reality we always applied the brake till full stop, air cooling alone would not already be sufficient.

It can be seen in Figure 5 that in case of slowing down from higher and higher speeds, the time necessary for removal of heat produced will also increase.

Let us determine the number of brake applications for 2 seconds of vehicles travelling at various

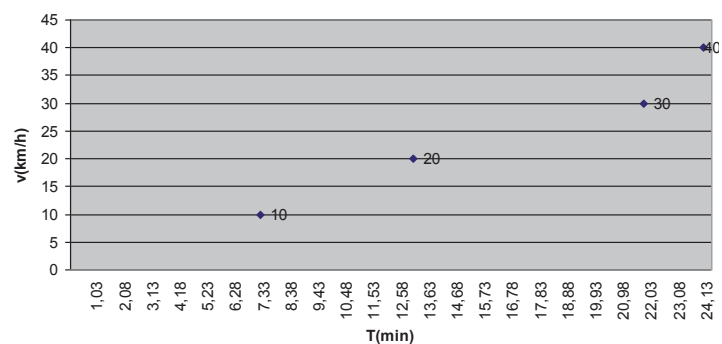

Fig. 5: The time necessary for removing the heat produced by air cooling when stopping a vehicle travelling at various rates by means of 2 seconds' braking.

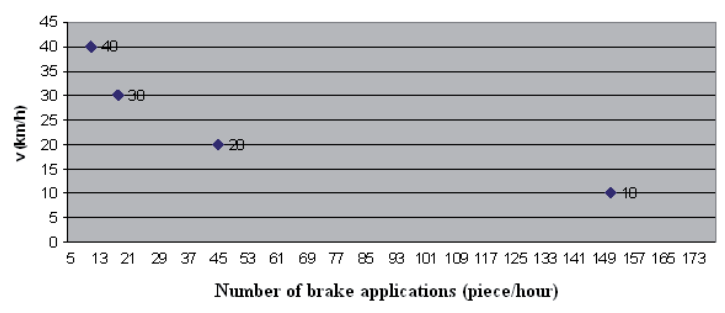

Fig. 6: Number of brake applications per hour of vehicle stopped from various speeds, in case of heat removal by air cooling and oil cooling.

speeds if the permitted wheel body wall temperature is $55^{\circ} \mathrm{C}$. Heat removal is done by air cooling and oil cooling.

From Figure 6 we can see that if during the slowing down of a vehicle travelling at various speeds both air cooling and oil cooling take part in removal of heat produced, then tendency of possible number of brake applications can be approximated with an exponential curve.

With the agricultural vehicle travelling at a rate of $40 \mathrm{kph}$, let us increase temperature of wheel body wall from $55^{\circ} \mathrm{C}$ to $80^{\circ} \mathrm{C}, 90^{\circ} \mathrm{C}$ then $120^{\circ} \mathrm{C}$. The heat produced is removed by air cooling and oil cooling. As temperature of wheel body wall increases, temperature of cooling oil increases proportionally. If wall temperature is $80^{\circ} \mathrm{C}$, then oil temperature is $90^{\circ} \mathrm{C}$, while in case of wall temperature of $90^{\circ} \mathrm{C}$, oil temperature increases to $100^{\circ} \mathrm{C}$, and in case of $120^{\circ} \mathrm{C}$ to $110^{\circ} \mathrm{C}$. The oil heater cools back the heated cooling oil to $640 \mathrm{C}$ in each case.

See how many brake applications can be done safely in one hour. Time of brake application continues to be 2 seconds.

It can be seen from Figure 7 that number of brake applications permitted hourly increases as the wheel body wall temperature increases.

Let us inspect number of brake applications as a 
function of wheel body wall temperature in case of slowing down from various speeds (10 kph, 20 kph, 30 kph, 40 kph). Both air cooler and oil heater participate in heat removal.

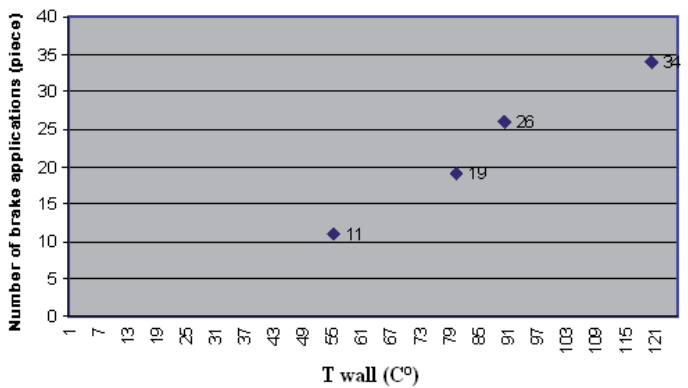

Fig. 7: Number of brake applications permitted hourly for the agricultural vehicle travelling at a rate of $40 \mathrm{kph}$ as a function of the wheel body wall temperature.

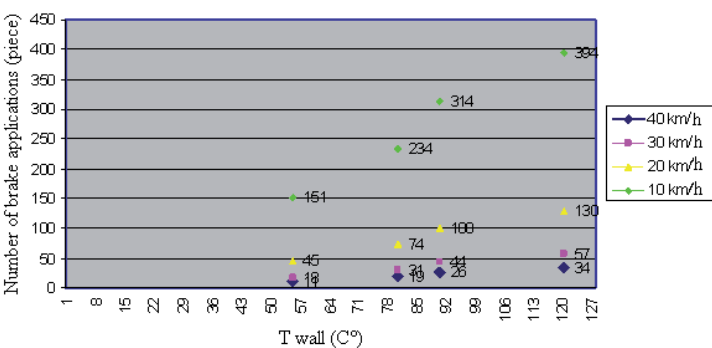

Fig. 8: Number of brake applications possible in one hour in case of stopping the vehicle travelling at various speeds.

\section{Inspection of oil}

In order for the equipment to operate properly, it is necessary to inspect not only the temperature form of each disc but also at what temperature the oil will damage.

According to the measurements done with platinum detectors placed in the separating disc, the maximum temperature of the separating disc after brake application is $298^{\circ} \mathrm{C}$. When the brake application is completed, the oil flowing between the separating disc and the brake disc heats up to the temperature of the separating disc, then the oil temperature significantly decreases while flowing towards the wheel body root. Life of oil is determined by the temperature at which the thermal decomposition occurs during the brake application.

\subsection{DSC Measurement}

The measurement was done by means of Differential Scanning Calorimeter (DSC) in inert atmosphere (nitrogen). Compensation principle is applied for the operation of the DSC device. High-pressure cell of equipment is suitable for the inspection of thermal oxidation of lubricating oils and heat stability as well.

DSC device can measure the heat flow taken up or given off by the chemical reaction of the oil sample and the temperature as the function of time. The enthalpy and specific heat capacity of the material as well as the temperature at which these changes take place can be defined by the help of this equipment.

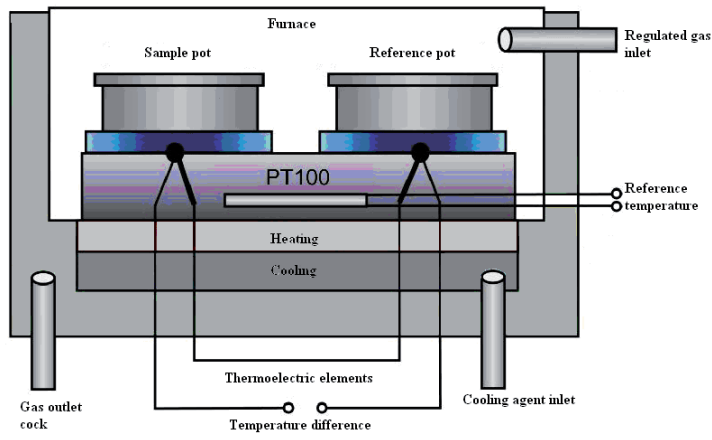

Fig. 9: Scheme of the Differential Scanning Calorimeter [7].

Main part of the device is the furnace, with two cells in equal positions found in it. The sample pot is placed in one of the testing cells, while the inert reference material is placed in the other reference cell. The sample material and the reference material separated in space are heated up in accordance with the same temperature program. Temperatures of the sample oil and the reference material are measured by a thermoelectric element each of the same type.
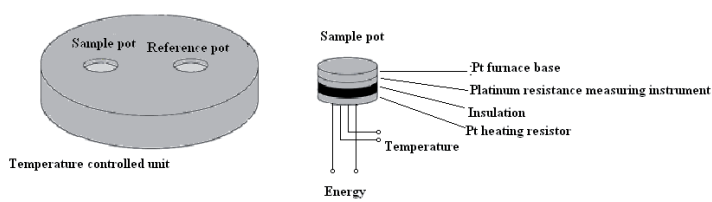

Fig. 10: Scheme of the temperature controlled unit [8].

\subsection{Measurement}

The calorimeter is operated in such a way that a pressure value is set, then the device is heated up quickly, after that the temperature of the oil capsule is increased continuously making sure that the process does not last for a long time.

Intensive damage of oil is shown by change of pressure or change of energy demand of heating. 


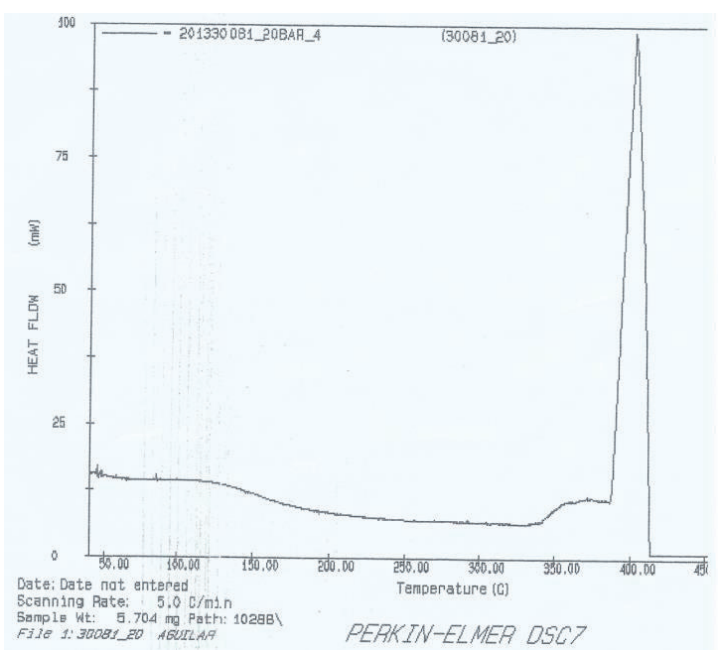

Fig. 11: Differential thermo-analytical diagram.

In this case, we evaluated the change of energy demand of heating.

The differential thermo-analytical diagram shows temperature in ${ }^{\circ} \mathrm{C}$ on the $\mathrm{X}$-axis, while heat flow rate in $\mathrm{mW}$ on the $\mathrm{Y}$-axis.

Oxidation of oil is a complicated process, consisting of two principal stages. The two peaks seen also in the measurement diagram represent it. The first peak is the oxidation at low temperature.

In this case, it can be observed already at $100^{\circ} \mathrm{C}$ at 20 bar pressure.

Water and organic oxidation products (alcohols, oxo compounds and acids) are released from the sample material. Then a residue rich in carbon is formed which is oxidized in the second stage.

During the measurement, the second stage occurs at $340^{\circ} \mathrm{C}$ temperature. The organic member compounds of large molecules go through thermal decomposition during the process. Since release of substance from the oil can be observed, it cannot be used any more.

Therefore we can state that the thermal stability limit of oil is between $340-350^{\circ} \mathrm{C}$.

Intensive damage of oil occurs at the temperature of $400+/-10^{\circ} \mathrm{C}$. At this temperature, the decomposition takes place at the greatest rate. Hydrocarbons decompose, evaporate and the heat flow taken up by the system decreases to $0 \mathrm{~mW}$.

The disc temperature of $300^{\circ} \mathrm{C}$ may be permitted if oil is loaded by the high temperature for a short time.

In the following, my study will aim at determination of average temperature of disc changing in the direction of radius. For the heat removal of the disc part dipping in the oil, the average temperature of the disc is authoritative. The temperature of the disc part is higher than that of the oil during the whole process. Temperature of the oil between the separating disc and the brake disc is approximately the same as the temperature of the discs. The disc part cooling in the oil significantly cools the disc part of greater diameter towards the root of the wheel body, while heating up the oil. Thereby, it influences the life of the oil.

\section{Summary}

The article describes how much time is necessary for the removal of the heat produced during brake application in case of safe slowing down of the vehicle travelling at various rates, with the heat removed by only air cooling or both air cooling and oil cooling.

It gives possible number of brake applications for various cases and values of heat transfer coefficient for different rates of travel.

It states the temperature above which the cooling oil will damage.

\section{References}

[1] Hans Faltin: Engineering Thermodynamics, Műszaki Könyvkiadó, Budapest, 1970.

[2] Dr. Zoltán Benedek, Dániel Hatházi, Endréné Kiss, Dr. Ferenc Konecsny, Dr. Endre Pásztor, István Perjési, Imre Sánta, István Steiger: Engineering thermodynamics and hydrodynamics II, Tankönyvkiadó Budapest, 1976.

[3] László Imre: Heat transmission in composite structures, Akadémiai Kiadó, Budapest, 1983.

[4] M. A. Mihejev: Bases of calculation of heat transfer in practice, Tankönyvkiadó Budapest, 1990.

[5] Pattantyús' Manual of Mechanical and Electrical Engineers, Volume 2, Múszaki könyvkiadó, Budapest, 1961.

[6] Dr. William S. Janna: Engineering Heat Transfer, CRC Press LLC, 2000.

[7] Sadik Kakac-Hongtan Liu: Heat Exchangers selection, rating and thermal design, CRC Press LLC, 1998.

[8] K. P. Szeleznyeva: Teplovoe szosztojanie rotorov i cilindrov napovih i gazabin turbin, Thermal condition of rotors and housings of steam and gas turbines, "Machine construction" publishing house, Moscow, 1964.

[9] Jászay Tamás: Engineering Thermodynamics, Addition of Heat, Múegyetemi kiadó, 1994.

[10] K. Ražnjević: Heat engineering charts, Műszaki Könyvkiadó, Budapest, 1964. 
[11] Menyhártné Baracskai Melinda: Thermodynamical examination of the oily disc brake of an agricultural motor vehicle, Periodica Politechnica, Transportation Engineering, Budapest. Just being published
[12] E.Pásztor: The determination of the optimum cool air mass flow of turbine blades at gas turbine aircrafts. M.V.M. Motorna Vozila i motori, International Congress Mot. (2006) Jugoszlavia, Kragujevac. pp.1-2.

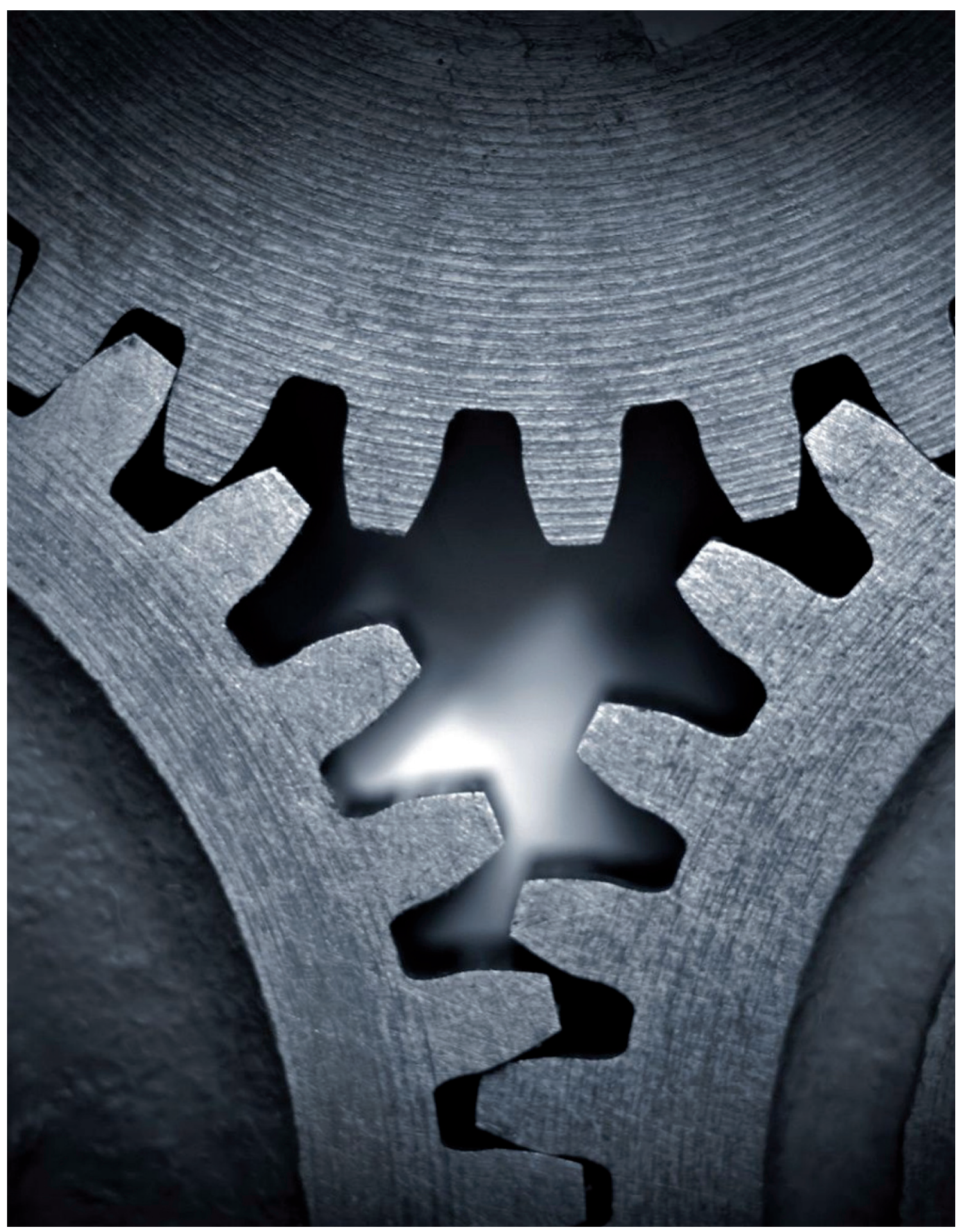

